СЕВЕРІНОВА О. Б., кандидат політичних наук, доцент кафедри юридичних дисциплін (Донеиький юридичний інститут Міністерства внутрішніх справ Украӥни)

УДК 340.11; 342.92

DOI https://doi.org/10.32842/2078-3736-2019-6-1-13

\title{
ІНФОРМАЦІЙНО-ПРАВОВИЙ ПРОСТІР: ПИТАННЯ РОЗВИТКУ В УМОВАХ РЕФОРМУВАННЯ
}

Стаття присвячена проблемам розвитку інформаційно-правового простору в умовах реформування. Критично проаналізовано наявні наукові погляди вчених щодо поняття «інформаційно-правовий простір» та надано авторське визначення. Вказано, що значення інформаційного простору змінювалося із часом виникнення України як юридично суверенної держави.

Проаналізовано основні характеристики національного інформаційного простору: територія, на яку безпосередньо чи опосередковано державою поширюється інформаційний вплив; структурованість інформаційного простору; інтенсивність інформаційних потоків.

Запропоновано міркування щодо подальшого розвитку інформаційно-правового простору в Україні. Особливо важливим питанням є законодавче визначення інформаційно-правового простору. В Україні діє велика кількість законодавчих актів, тому доведено необхідність кодифікації правових норм інформаційно-правового простору, а саме ухвалення Інформаційного кодексу у зв'язку з наявністю певних властивостей, які істотно відрізняють такі відносини від традиційних. Саме Інформаційний кодекс стане ефективним правовим інструментарієм зі створення сприятливих умов розвитку інформаційно-правового простору, уніфікації відповідного законодавства, усунення неточностей щодо розуміння інформаційно-правових процесів тощо.

В умовах, коли Україна взяла курс на діджиталізацію всієї країни, цікавим $\epsilon$ виокремлення інтернет-правового простору, який повинен визначати загальнотеоретичні питання права й Інтернету; відносини права віртуального простору й Інтернету (інтернет-відносини); відповідальність за інтернет-правом; правосвідомість, правову культуру та правове виховання суб'єктів інтернет-відносин.

Ключові слова: інформаційно-правовий простір, інформачія, інформачійне суспільство, інформаційне середовище, інформаційна сфера, інформаційне законодавство.

The article is devoted to the problems of development of information-legal space in the conditions of reforming. Critically analyzed existing scientific views of scientists on the concept of "information-legal space" and provided the author's definition. It is stated that the value of the information space has changed with the emergence of Ukraine as a legally sovereign state.

The basic characteristics of the national information space are analyzed: the territory to which information influence from the state is directly or indirectly distributed; structured information space; the intensity of information flows.

Considerations are given for the further development of the informationlegal space in Ukraine. A particularly important issue is the legislative definition

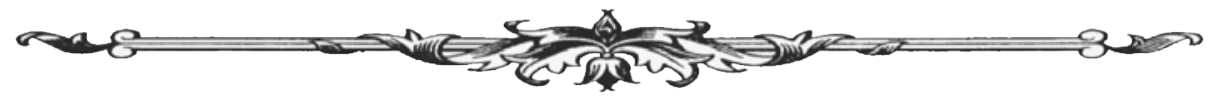


of the information-legal space. In Ukraine, a large number of legislative acts is in force, which is why it is necessary to codify the legal norms of the informationlegal space, namely the adoption of the Information Code due to the presence of certain properties that significantly differentiate such relations from traditional ones. It is the Information Code that will be come an effective legal tool for creating favorable conditions for the development of the information-legal space, unification of the relevant legislation, elimination of inaccuracies in the understanding of information and legal processes, etc.

In the context of Ukraine taking a course on the digitization of the whole country, it is interesting to identify the Internet-legal space, which should determine the general theoretical issues of law and the Internet; virtual space / internet law relationships (Internet relations); responsibility for Internet law; legal awareness, legal culture and legal education of subjects of Internet relations.

Key words: information-legal space, information, information society, information environment, information sphere, information legislation.

Вступ. У сучасний період суспільство розвивається під впливом інтеграційних, глобалізаційних та інших процесів, до яких варто віднести інформаційний. В останнє десятиліття інформаційна сфера стала найважливішим чинником розвитку суспільства, а інформатизація всіх сфер суспільної діяльності є основним напрямом державної політики й імперативом розвитку суспільства. Інформація впливає на розвиток економічної, соціальної, наукової, культурної сфери, інститутів громадянського суспільства та держави взагалі; формування і розвиток нових економічних, соціальних та інших відносин, зокрема на гарантування безпеки України та іï національних інтересів. Тобто інформаційні процеси впливають на всі сфери суспільства у зв'язку з універсальним характером інформації, iї природними особливостями. Але розвиток інформації можливий тільки в межах правового простору. В умовах реформування не тільки законодавства, а майже всіх сфер суспільного життя актуалізується питання визначення інформаційно-правового простору. Особливістю дослідження є те, що право має регулятивну функцію щодо інформаційного простору, у свою чергу, інформаційний простір впливає на розвиток права. Це спонукає до переосмислення деяких державно-правових поглядів, теоретико-правових цінностей, зокрема стосовно інформаційно-правового простору. Тому дослідження із цієї тематики є своєчасним і необхідним.

Зауважимо, що деякі аспекти окресленої тематики дослідження розглядали у своїх працях такі вчені, як: В. Авер'янов, І. Арістов, Ю. Битяк, К. Бєляков, В. Брижко, А. Гулемін, Р. Калюжний, Л. Коваленко, Б. Кормич, О. Кохановська, В. Ортинський, О. Олійник, О. Остапенко, В. Пилипчук, А. Пухтецька, Ю. Шемшученко, О. Яременко й інші. Але з урахуванням впровадження нових підходів до інформації, удосконалення понятійного апарату можна констатувати, що багато аспектів регулювання інформаційно-правового простору залишаються відкритими.

Постановка завдання. Метою дослідження стало визначення поняття інформаційно-правового простору та виявлення особливостей розвитку в умовах реформування й інтегрування України в європейське співтовариство.

Результати дослідження. Процеси модернізації суспільства розвивають сучасну галузь правового регулювання - інформаційну, яка складається з багатьох елементів. Як уже підкреслювалося, інформаційний простір може існувати тільки в межах правового простору, якщо метою є сталий, стабільний розвиток суспільства і держави. Саме правове регулювання повинно впорядкувати суспільні інформаційні відносини, що виникають у процесі здійснення взаємодії, забезпечуючи реалізацію і захист прав та інтересів громадян, суспільства, держави. Одним з основних чинників розвитку держави є формування єдиного інформаційного-правового простору, що забезпечує діяльність усіх суб'єктів, зокрема громадян. Сьогодні відбувається активний процес формування такого єдиного інформаційно-правового

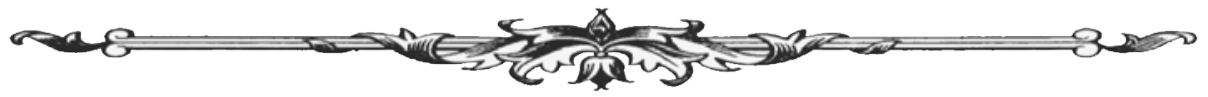


простору в Україні. Особливим об'єктом інформаційних правовідносин і елементом інформаційно-правового простору є інформація.

Варто наголосити, що дотепер немає єдиного тлумачення поняття «інформаційно-правовий простір». Значення контенту інформаційного простору змінювалося із часом виникнення України як юридично суверенної держави. До розпаду Радянського Союзу на всій його території, з Україною включно, був єдиний тоталітарний, комуністично-радянський інформаційний простір, де використовувалася лише та інформація, яка відповідала ідеології панівної авторитариської партії. 3 набуттям незалежності в Україні почав формуватися свій власний національний інформаційний простір. Проте він поки що продовжує залежати від «інформаторів» інших країн [1, с. 54]. За допомогою історичного методу можна зробити висновок, що сучасні нормативні акти, які регулюють відносини, де об'єктом є інформація, не містять уніфікованої термінології. Наприклад, в інформаційній сфері вживають такі терміни, як: «інформація», «інформаційний простір», «інформаційна сфера», «інформаційно-правовий простір», «сфера інформації» тощо. Крім того, існують термінологічні неточності, різне тлумачення однакових за назвою і за формою понять і категорій і в теорії права, що призводить до їх неоднозначного розуміння та правозастосування.

У літературі зазначають, що в більшості публікацій обгрунтування категорії «інформаційний простір» зводиться до його розгляду як певної геополітично визначеної території, яка є сувереном щодо поширення на ній текстової, звукової, аудіовізуальної й ілюстративної інформації через канали засобів масової інформації [2, с. 104].

А. Манойл визначає інформаційний простір як сукупність суб'єктів інформаційної взаємодії чи впливу; інформації, призначеної для використання суб'єктами інформаційної сфери; інформаційної інфраструктури, що забезпечує можливість обміну між суб'єктами; суспільних відносин, які формуються як наслідок утворення, передачі, поширення і зберігання інформації, обміну інформацією всередині суспільства [3, с. 73].

А. Семенов зазначає, що інформаційний простір - це територія поширення інформації за допомогою конкретних компонентів системи інформації та зв'язку, діяльність якої має гарантоване правове забезпечення. Спеціальними вимірами інформаційного простору можуть стати: загальна кількість засобів масової комунікації, загальний обсяг іії продукції, що поширюється і приймається на певній території; опосередкована фіксація тих або інших результатів контакту із продукцією засобів масової комунікації реципієнтів [4, с. 91-93].

О. Солдатенко вважає, що інформаційний простір - це сукупність інформаційних об'єктів, які поширюються його суб'єктами через наявні засоби комунікації, тобто контролю можуть підлягати: об'єкти, суб'єкти та засоби комунікації. До інформаційних об'єктів належать друкована продукція, радіо, телебачення, супутникове мовлення, яке об'єднує в собі телерадіомовлення й Інтернет [5, с. 134-140].

О. Селезньова підкреслює, що в літературі категорії «інформаційна сфера», «інформаційний простір» та «інформаційне середовище» ототожнюються i/або трактування одного терміна здійснюється через вживання іншого (наприклад, О. Логінов розглядає інформаційну сферу України як «єдиний інформаційний простір, який формується державними органами, громадськими, політичними та соціальними організаціями, а також громадянами й функціонує з урахуванням правових, організаційних, науково-технічних, економічних, фінансових, методичних, гуманітарних та моральних засад з урахуванням вимог та завдань національної інформаційної безпеки України» [6, с. 9], ототожнюючи водночас категорії «інформаційна сфера» й «інформаційний простір» та звужуючи обсяг поняття «сфера» до обсягу поняття «простір», застосувавши територіальне обмеження). Такі позиції, на думку науковця, у своїй основі неправильні, оскільки кожна з вищевказаних категорій має своє тлумачення. Навіть більше, в інформаційному законодавстві визнається їхня нетотожність [7]. Зокрема, у п. 8 ч. 1 ст. 3 Закону України «Про інформацію» зазначено, що одним 3 основних напрямів державної політики $є$ сприяння міжнародній співпраці в інформаційній сфері та входження України до світового інформаційного простору [8]. Також О. Селезньова визначає інформаційний простір як частину інформаційної сфери, що обмежується

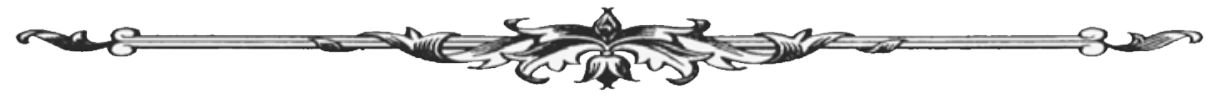


територією держави, союзу держав або віртуальним суспільством. Тобто інформаційний простір може бути територіальним (інформаційний простір держави, європейський інформаційний простір, світовий інформаційний простір) або віртуальним інформаційним простором. Інформаційне середовище вона визначає як частину інформаційного простору, що характеризується мінімальною територією поширення й обмеженою кількістю суб' єктів інформаційної діяльності, а також зумовлюється своєрідним інформаційним мікрокліматом, що включає сукупність способів, прийомів, заходів і умов безпосереднього здійснення інформаційної діяльності [7].

М. Шевченко пише, що в контексті нашої держави застосовується категорія «національний інформаційний простор України». Законодавче визначення його обгрунтовується так: «Національний інформаційний простір України - сфера (об’ємний простір), у якій здійснюються інформаційні процеси і на яку поширюється юрисдикція України» [8]. Вчена зазначає, що існування державного інформаційного простору часто є єдиною (але безпомилковою) ознакою національної ідентифікації. Основні характеристики національного інформаційного простору:

- територія, на яку державою безпосередньо чи опосередковано поширюється інформаційний вплив. Межі інформаційного впливу мають збігатися з їі державними кордонами. Це ареал, у якому діють усі складові частини інформаційного простору: радіо, преса, телебачення;

- структурованість інформаційного простору. Інформаційний простір є динамічним утворенням, що розширюється та конкретизується разом із розвитком нашого суспільства;

- інтенсивність інформаційних потоків. Це рух повідомлень структурами інформаційного простору. Окрім масмедіа, до інформаційних потоків можна віднести такі сфери людської діяльності, як туризм, міграцію, освітні, культурні обміни, конференції, змагання й ін. Інформаційні потоки являють собою циркуляцію інформації, окреслюють ії напрями i форми, що спричинює зміни на різних рівнях і в різних системах, а саме: зміни у природі, ресурсах, управлінні, культурних і національних системах [2, с. 106].

На основі аналізу висловлювань учених можна зробити власний висновок, що інформаційно-правовий простір - це сукупність інформаційних ресурсів, які існують на території держави та діють на підставі нормативних актів, спрямованих на забезпечення взаємин між фізичними та/або юридичними особами та/або державою з метою задоволення їхніх інформаційних потреб за врахування збереження балансу інтересів і забезпечення національного інформаційного суверенітету.

Інформаційно-правовий простір складається з інформаційних і телекомунікаційних систем та мереж зв'язку, індустрії засобів інформатизації, телекомунікації і зв'язку; систем формування і забезпечення збереження інформаційних ресурсів; системи забезпечення доступу до інформаційно-телекомунікаційних систем, мереж зв'язку й інформаційних ресурсів; індустрії інформації та ринку інформаційних послуг; системи підготовки кадрів, проведення наукових досліджень; алгоритмів і програмних засобів, що забезпечують функціонування програмно-апаратних платформ тощо [9, с. 22]. Але в умовах, коли Україна взяла курс на діджиталізацію всієї країни, цікавим є виокремлення інтернет-правового простору, який повинен визначати загальнотеоретичні питання права й Інтернету; відносини права віртуального простору й Інтернету (інтернет-відносини); відповідальність за інтернет-правом; правосвідомість, правову культуру та правове виховання суб' єктів інтернет-відносин.

Діджиталізація (цифрові технології) приходить на заміну старим засобам електронної комунікації - телефону, факсу, телеграфу. Вона означає зміну не тільки в тому, як ми комунікуємо, але й у тому, що ми комунікуємо. Нові цифрові технології дозволяють створювати і поширювати величезні обсяги інформації майже необмеженому колу осіб - швидко, якісно, без будь-яких істотних витрат [10]. Тому дослідження інтернет-правового простору є актуальним і перспективним.

Особливо важливим питанням $є$ законодавче визначення інформаційно-правового простору. Нині в Україні діють багато законодавчих актів: закони «Про Основні засади

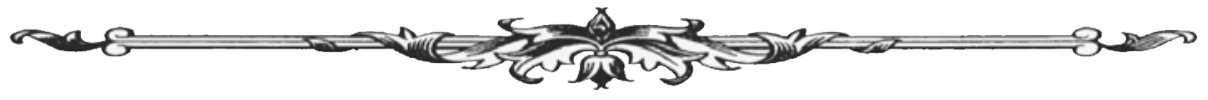


розвитку інформаційного суспільства в Україні на 2007-2015 рр.», «Про електронний цифровий підпис», «Про інформацію», «Про друковані засоби масової інформації (пресу) в Україні», «Про державну таємницю», «Про Концепцію національної програми інформатизації», «Про Національну програму інформатизації», «Про науково-технічну інформацію», «Про захист інформації в інформаційно-комунікаційних системах», «Про електронний цифровий підпис», «Про електронні документи та електронний документообіг», «Про захист персональних даних» тощо.

Інформаційно-правовий простір не може розвиватися, спираючись на численну кількість нормативних актів. Черговим етапом розвитку має стати кодифікація правових норм даної сфери, а саме розроблення й ухвалення Інформаційного кодексу. Саме Інформаційний кодекс стане ефективним правовим інструментарієм для створення сприятливих умов розвитку інформаційно-правового простору, уніфікації відповідного законодавства, усунення неточностей щодо розуміння інформаційно-правових процесів тощо. На теперішній час інформаційно-правовий простір регулюється нормами цивільного, господарського, адміністративного, інтелектуального й інших галузей права. Отже, кодифікований акт дозволить уникнути різного тлумачення в законодавстві та перенесення одних норм в інші галузі права. Щодо ухвалення Інформаційного кодексу, то варто підкреслити, що, на відмінну від інших суспільних відносин, інформаційні відносини характеризуються знеособленістю та наявністю безпаперових (електронних, цифрових) документів, які мають особливий порядок користування.

Висновки. На підставі вищезазначеного можна зробити висновок, що інформаційно-правовий простір - це сукупність інформаційних ресурсів, які існують на території держави та діють на підставі нормативних актів, спрямованих на забезпечення взаємин між фізичними та/або юридичними особами та/або державою з метою задоволення їхніх інформаційних потреб за врахування збереження балансу інтересів і забезпечення національного інформаційного суверенітету.

Як складову частину інформаційно-правового простору виокремлено інтернет-правовий простір, який повинен містити загальнотеоретичні питання права й Інтернету; відносини права віртуального простору й Інтернету (інтернет-відносини); відповідальність за інтернет-правом; правосвідомість, правову культуру та правове виховання суб'єктів інтернет-відносин.

В Україні немає комплексного закону щодо регулювання інформаційно-правового простору, де було б визначено статус суб'єктів, зміст відносин; використання встановлених законом способів і методів; норми щодо юридичної відповідальності тощо. Тому доведено необхідність кодифікації правових норм інформаційно-правового простору, а саме ухвалення Інформаційного кодексу у зв'язку з наявністю певних властивостей, які істотно відрізняють такі відносини від традиційних. Наголошено, що в сучасних умовах розвитку України не можна допустити примітивізації регулювання інформаційно-правового простору, необхідна розробка уніфікованого понятійного апарату.

\section{Список використаних джерел:}

1. Микулець В. Сдиний інформаційний простір: формування та застосування у сфері забезпечення безпеки дорожнього руху в Україні. Історико-правовий часопис : журнал / упоряд. О. Крикунов. Луцьк : Східноєвроп. нац. ун-т ім. Лесі Українки, 2014. № 1 (3). С. 53-58.

2. Шевченко М. Поняття національного інформаційного простору та його характеристики. Украӥнський інформаційний простір. 2018. № 1. С. 103-113.

3. Манойло А. Государственная информационная политика в особых условиях : монография. Москва : МИФИ, 2003. 388 с.

4. Семенов А. Захист національного інформаційного простору Великої Британії. Політична праксеологія: безпека, технології, комунікації : матеріали Міжнародної конференції / за ред. В. Бебика. Київ : ВАПН, 2016. 117 с.

5. Солдатенко О. Інформаційний простір у мережі Інтернет: правове регулювання та контроль. Підприємнищтво, господарство і право. 2018. № 5. С. 134-140.

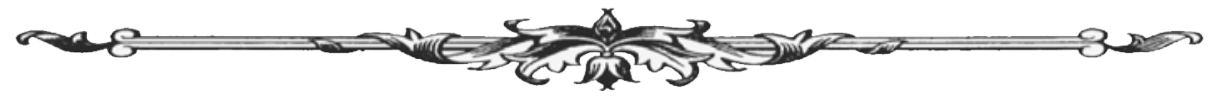


6. Логінов О. Адміністративно-правове забезпечення інформаційної безпеки органів виконавчої влади : автореф. дис. ... канд. юрид. наук: 12.00.07. Київ, 2005. 23 с.

7. Селезньова О. Теоретико-методологічне трактування окремих засадничих категорій інформаційного права. URL: http://aphd.ua/publication-164/.

8. Про інформацію : Закон України в редакції від 13 січня 2011 р. № 2938-VI $з$ наступними змінами та доповненнями. URL: http://zakon2.rada.gov.ua/laws/show/2657-12.

9. Дубняк К. Інформаційний простір: структура та функціональні параметри. Держава та регіони. Серія «Соціальні комунікаиії». 2015. № 4 (24). С. 21-25.

10. Кібенко О. Діджиталізація як нова ера розвитку корпоративного права. Судебно-юридическая газета. Блог. URL: https://sud.ua/ru/news/blog/145948-didzhitalizatsiyayak-nova-era-rozvitku-korporativnogo-prava.

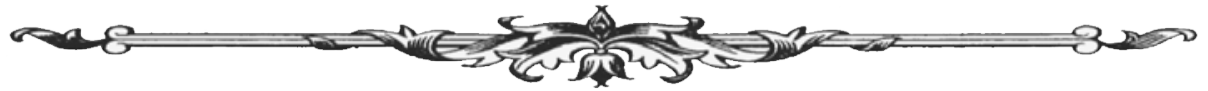

